\title{
THE ROLE OF HOME GARDENING IN HOUSEHOLD FOOD SECURITY IN BUTERE DIVISION OF WESTERN KENYA
}

\author{
Musotsi AA*1 ${ }^{1}$ AJ. Sigot ${ }^{2}$ and MOA Onyango ${ }^{3}$,
}

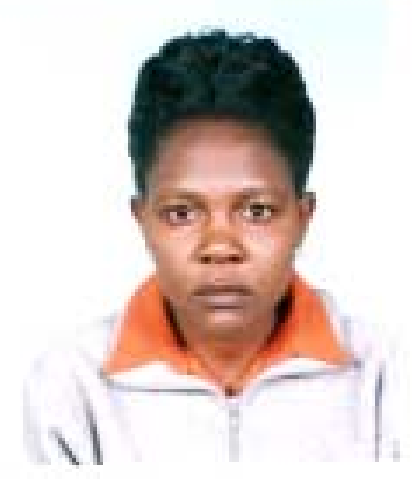

Anne Aswani Musotsi

*Corresponding author email: annemuske@yahoo.com

${ }^{1}$ C/O KIM- Nakuru Branch, P.O. Box 12692, Nakuru, KENYA.

Cell phone: 0720365208

Corresponding author E-mail: annemuske@yahoo.com

${ }^{2}$ Ag. Dvc- Academic Affairs MMUST, P. O. Box 190, Kakamega, KENYA.

Cell Phone: 0722612160

E-Mail: sigot@africaonline.co.ke

${ }^{3}$ Department of Horticulture, JKUAT, P.O. Box 62000-00200, City Square, Nairobi, KENYA.

Cell Phone: 0722676907

E-mail: mabukutsa@yahoo.com 


\begin{abstract}
Gardening remains the most important method of food production for a majority of people in the developing world, yet high population density has put a lot of pressure on land as more of it is required for settlement. This has led to land fragmentation, which has negatively affected food production, hence, resulted in food insecurity. Food insecurity is a concern today in many parts of Kenya. Land use practices thus have to be intensified to maximize food production on the small land available. Home gardening has been identified as a means of providing all year round access to food for rural households. Home gardens can make a significant contribution in meeting daily household needs for better nutrition and health. A study was carried out among rural households in Butere division, western Kenya, to determine the role of home gardening on household food security. Simple random sampling was used to obtain a study population of 100 households, to whom an interview schedule and an observation checklist was administered. Twenty key informants were purposively sampled and responded to questionnaires. Data obtained were analyzed quantitatively. Pearson correlation coefficient was applied on home gardening indicators: size of land for home gardening, home garden crops and home garden livestock, and food security indicators: food stock and number of meals eaten daily by households. Results obtained showed that home gardening plays a significant role in food security of rural households with respect to size of land and food stock $(0.336$ at $\mathrm{p} \leq 0.01)$, and number of livestock and food stock $(0.211$ at $\mathrm{p} \leq 0.05)$. Home gardening did not play a significant role in food security with regard to home garden crops. Households, therefore, should be empowered and encouraged to improve their practice of home gardening to realize food security. Findings of this study will be useful to governmental and non-governmental bodies involved in promoting food security in the rural households.
\end{abstract}

Key words: Home gardening, household food security 


\section{INTRODUCTION}

For many generations, small plots of land near the homestead have been used as home gardens [1] while livestock keeping has also been practiced in Africa. This has been done to facilitate direct access by households, to a diversity of nutritionally rich foods, which include roots, tubers, green leafy vegetables, condiments, nuts, legumes, fruits and livestock products [2,3]. Whereas the practice of home gardening is a supplementary food production system and not the household's primary source of food, it is increasingly becoming popular with households as the size of land for food production continues to reduce [4]. While developed countries exhibit high technological advancement in food production, gardening remains the most important method of food production for a majority of people in developing countries, Kenya included. Research findings on food production in Kenya have shown that over the last decade there has been a decline in food production, while the population size has been increasing $[4,5,6]$. This has created a food gap, with $89 \%$ Kenyans being food poor and a majority of these people being in the rural areas [5]. The issue of concern is why this is happening despite the focus of the country's food policy being to encourage food self-sufficiency as the means of achieving food security.

Food insecurity has been identified as the prime cause of malnutrition while poverty has been shown to be one of the underlying causes of food insecurity [7]. Malnutrition has consequences ranging from morbidity to mortality. Food security, being one of the Millennium Development Goals (MDGs), requires a nutritionally adequate and safe food supply at both national and household levels, a reasonable supply of food during the year and in all years, and access by each household to sufficient food to meet the needs of all [8]. However, for a number of households in Butere division of Butere-Mumias district in Western Province of Kenya this remains unattainable [4, 6]. This could be attributed partly to the fact that food production strategies have not maximized the available land and the high agricultural biodiversity in western Kenya [4]. Seasonal hunger has been rampant in this part of Kenya, year in year out during which household food needs are not adequately met. Some indicators of seasonal hunger at household level include depletion of food stocks, reduction in number of meals eaten daily and increased dependence on home garden crops. There is, therefore, need to address the issue of food insecurity, with the aim of preventing the current situation from degenerating into a chronic state.

Butere division lies in the sugar belt zone. Various factors that have led to food poverty have been identified, including high population growth rate, poor land use, slow maturation of sugarcane, which covers most of the land, the negative impact of the Human Immuno-Deficiency Virus (HIV) and Acquired Immuno-Deficiency Syndrome (AIDS), and households headed by people without formal education [4]. The food insecurity situation in Butere division has led to government and nongovernmental agencies proposing the empowerment of individuals and households to intensify food production on the small lands available. Efforts have to be made at household and community levels to ensure food security for households in order to achieve sustainable rural livelihoods. Thus, one of the priorities in promoting food

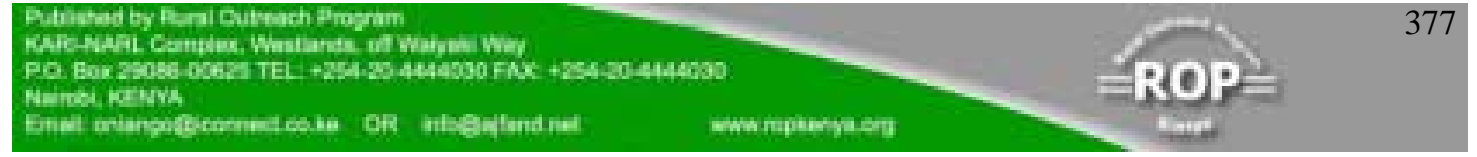


security by the District Poverty Reduction Strategy team is development of home gardens [4].

The objective of this study, therefore, was to determine the relationship between home gardening and household food security. The study sought to answer the following questions:

- Do households in Butere division practice home gardening?

- Does home gardening play a role in household food security?

\section{Conceptual Framework}

This research used a modified model that indicates causative factors affecting food production and food availability in the household [9]. In this model, food available in the household is identified as a factor that eventually affects nutritional status of a family and an individual. However, this study will consider the influence of various processes affecting availability of food in the household. The interrelations of various factors can be expressed as a flow of resources determining food availability. In this model, Mason et al. [9] conceptualize the relationship of resources and flow variables to nutritional outcome. Among the resources are land, technology, labor, climate, education and environment. All these affect food production and thus the success of strategies such as home gardening.

Food production in most rural households predicts food status of the individual household. The model shows that land, technology, labor, climate, education and environment affect food production and food availability at national, community, household and individual levels, which in turn affects nutritional. This may also be affected by income whereby money influences food purchases. In Butere division, income becomes important during seasonal hunger when households have to make food purchases almost on a daily basis. The focus of this study was on how home gardening, which is aimed at food production affects household food availability. 
Figure 1: $\quad$ Relation of flow of variables to food availability in the household: hypothesized model for the study, modified from Mason et al. (1984)

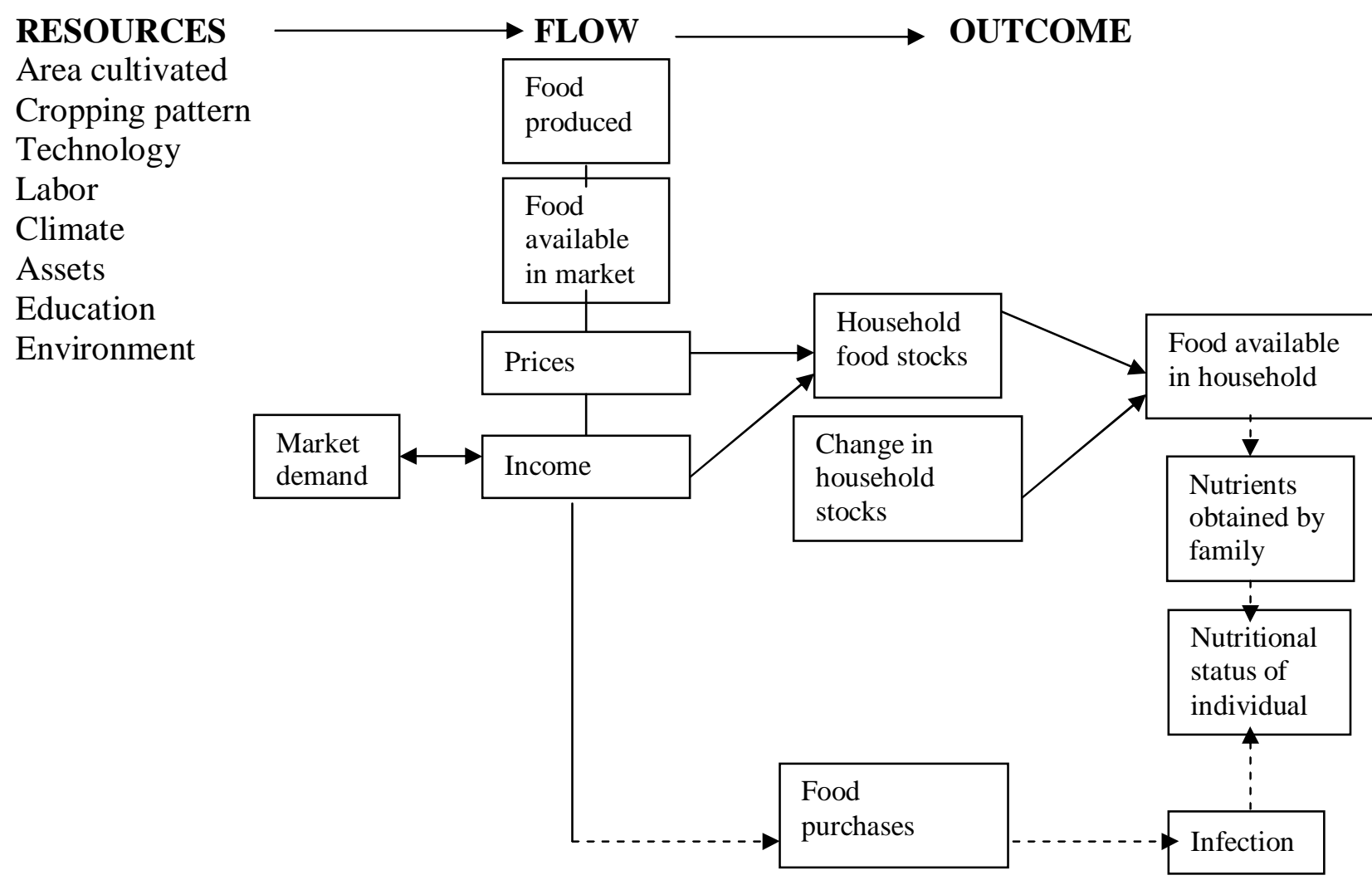

Flow of factors that affect food availability at household level

Flow of factors that affect nutritional status 


\section{AREA AND TIME OF STUDY}

Butere division whose altitude ranges between $1,250 \mathrm{~m}$ and $1,641 \mathrm{~m}$ above sea level is located within Butere district of western Kenya. This part of Kenya is largely rural, with a majority of the population having agriculture as their main source of livelihood. It is endowed with a high agricultural bio-diversity and good rainfall almost the whole year round, allowing farmers to have two cropping seasons. The mean annual temperatures are $29^{\circ} \mathrm{C}$ while the soils range from sandy loams, clay loams and well-drained loam soils. Food crops and livestock are reared on subsistence level and a majority of the farmers are peasant. Other than food crops, sugarcane is grown as the main cash crop. Butere division covers $209.8 \mathrm{sq}$. Km, with a population density of 600 persons per sq. $\mathrm{km} \mathrm{[10].} \mathrm{This} \mathrm{high} \mathrm{population} \mathrm{density}$ coupled with poor soils in some parts that cannot support a variety of crops, has led to pockets of poverty springing up in parts of the district.

This study was carried out between January and March 2003, which is the driest season in western Kenya. Thus, farming activities were minimal and except for drought resistant crop varieties and home garden crops, most farms had no crops. The time also symbolizes the onset of seasonal scarcity of food, which is marked by lack of staple food (maize meal) at the household level. Most families, therefore, rely on home garden crops and livestock for income and supply of food.

\section{METHODS}

A descriptive survey design was used in the study [11, 12], which targeted rural households of Butere division. A sample size of 100 households was obtained using simple random sampling while 20 key informants were purposively selected for the study. The data gathered from key informants were used as a quality check. Data were collected using a self-administered questionnaire for the key informants, and an interview schedule and an observation checklist for the households. The data obtained were analyzed quantitatively using the Statistical Package for Social Sciences (SPSS) 8.0 for windows version. Descriptive statistics were used to generate frequency distribution and percentages for agro-economic data [12, 13, 14]. Cross tabulation and filtering were done to summarize data for home gardening indicators: size of land, home garden crops and number of livestock. Similarly, food security indicators: food stock and number of meals eaten daily within a household [15] were summarized. The Pearson Correlation Coefficient was then applied to determine the relationship between home gardening indicators and food security indicators [13].

\section{RESULTS}

Results revealed that $100 \%$ households practiced home gardening. Table 1 shows the distribution of households by crops raised in the home gardens while table 2 summarized the distribution of households by the number of livestock reared. There were no regular farming activities due to the drought. Livestock included sheep, cows, goats, poultry and fisheries all on peasant scale.

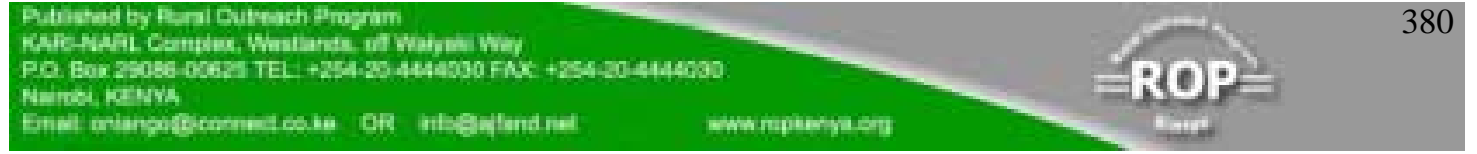


Results of the Pearson Correlation Coefficient in table 3 showed that the correlation between size of land for home gardening and food stock at 0.336 was significant $(\mathrm{p} \leq 0.01$ This indicates a moderate increase in food stocks at household level as a result of a corresponding change in size of land. Thus households with bigger land sizes had more food stock as compared to those with smaller pieces of land. There was no significant correlation ( $p>0.05)$ between size of land for home gardening and number of meals eaten daily. A correlation of 0.133 was obtained implying that minimal changes in number of meals resulted from change in size of land that a household gardens. Similarly, results of the correlation between home garden crops and food stock was not significant $(\mathrm{p}>0.05)$ with a correlation of 0.117 , indicating that minimal changes in food stock were as a result of changes in home garden crops. There was also no significant relationship $(\mathrm{p}>0.05)$ between home garden crops and number of meals eaten daily. The correlation coefficient obtained was 0.000 , implying that changes in home garden crops did not at all affect changes in number of meals eaten daily by households. The correlation between number of livestock and food stock was significant $(\mathrm{p} \leq 0.05)$ with a correlation coefficient of 0.211 . This implies that moderate changes in food stock could be accounted for by changes in number of livestock. Lastly, the correlation between number of livestock and number of meals eaten daily was insignificant ( $p>0.05$ ) with a correlation of 0.064 . This implies that very minimal changes in the number of meals eaten daily occurred due corresponding changes in number of livestock.

The above results, therefore, reveal that home gardening plays a significant role in household food security with respect to size of land for home gardening and number of livestock but not with home garden crops.

\section{DISCUSSION}

Results indicate that home gardening is a known concept among households in Butere division. However, the results of the observation checklist revealed that most of the home gardening activities were done in a haphazard way, using traditional farming methods such as use of uncertified seeds, broadcasting of seeds, very little or no use of manure or fertilizers and lack of a fence around the home garden. This may affect the amount of food produced thus impacting negatively on the household food supply $[16,17]$. Modern ways embrace the use of certified seeds, planting in rows, use of manure or fertilizers and fencing to protect the garden from domestic animals and livestock. But these have not been utilized because of lack of capital and also lack of knowledge. Further, there seems to be a decline in production of traditional food crops namely indigenous vegetables, root crops, nuts, sorghum and millet as shown in table 1. According to Kenya Government Sessional paper No.2 on National Food Policy these crops should be promoted as they are drought resistant and can improve household food security [16].

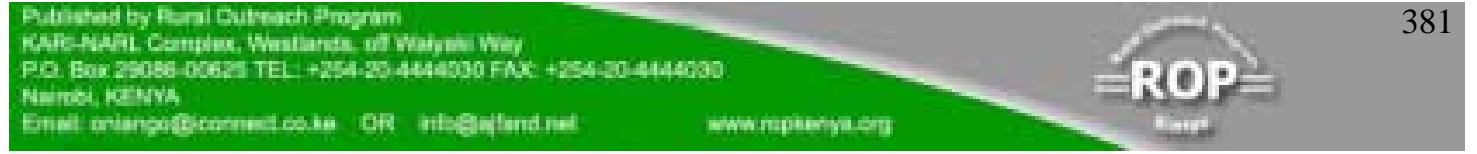


The size of land used for home gardening by a household was found to affect food stocks in Butere division, western Kenya. The larger the land size, the more the food stocks. This could be explained by factors such as lack of modern farming methods that can intensively produce food from small lands and also poor land use practices [4]. The average land size in Butere division as documented in the District Development Plan is 3.5 acres for small-scale farmers who are a majority [4]. Most of this land is also under sugarcane production. This study, however, found out that $86 \%$ of the sampled households had land size of 3 acres and below. The reduction in size of land thus pre-disposes households to food insecurity, as they will not produce enough food to stock for lean seasons. The finding may imply that households need to invest more in food crop production using modern and intensive farming methods such as mixed farming and intercropping.

Results also showed that the size of land a household owns in Butere division did not play an important role in the number of meals eaten daily within the household. This finding could be explained by the fact that other methods of procuring food may be employed, such as buying [16] and gathering [18]. These two methods were identified by households as the most important methods used to supplement household food shortages in seasonal hunger. The main foods bought are maize, vegetables and root crops while foods gathered are wild vegetables, fruits, mushrooms and insects. However, buying food is expensive for a majority poor in Butere division, while gathering is affected by reduction of plant species from the wild thus not feasible methods for ensuring household food security. It is of utmost importance, therefore, that households produce sufficient food from their gardens to last the year round.

Home garden crops did not play an important role in relation to food stocks. This may be attributed to the low yields from home gardening in Butere division as revealed in table 1. When more of home garden crops such as root crops, bananas and nuts are produced, they can be used as meals and snacks thus allowing for stocking of cereals, legumes and other foods that can be stored for long-term use. Also, there is a possibility that preservation methods could affect storage of home garden crops such as vegetables, thus causing surpluses to go to waste. Sun-drying is the commonly used method of food preservation for a majority of the households in Butere division.

The role played by home garden crops on a number of meals eaten daily was insignificant. This could be as a result of low consumption of these crops at household level. Many households depend on sale of their foodstuffs, particularly home garden foods, to meet other basic needs such as clothing, healthcare and school fees $[4,10]$. Further, data from key informants elicited $75 \%$ responses to the affirmative for selling of farm produce by households. Although home gardens can be income generating [10], this should be done only when the household food needs have been met. Households should be encouraged to increase home garden produce, so that there is enough to consume, preserve for future use and sell surpluses for income. This is needful for food security and good nutrition. In the case of dairy products such as milk, incorporation into other meals such as tea and vegetables makes them

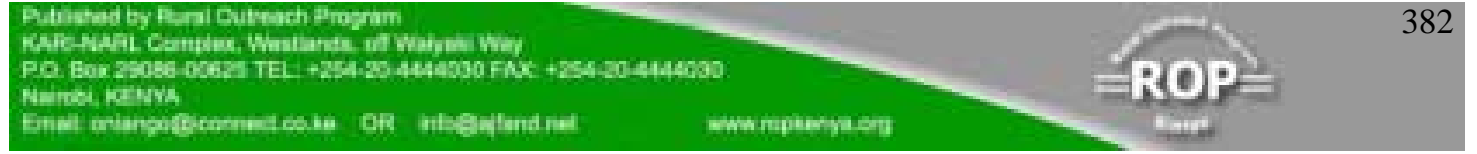


insignificant as a meal on its own. Yet, they do play a role in food security thus should be encouraged.

Findings of the study showed that an increase in number of livestock leads to an increase in food stocks. A possible explanation for this could be the fact that livestock waste, being useful in farming is utilized in order to improve yields. Studies have shown that the inter-depended ness of a home garden enables a household realize better yields [17], such as the animals consume waste plants from the garden, and return nutrients to the soil in their manure. From observation, a remarkable percentage of the households in Butere division who had livestock also had a pit for preparing farmyard manure. When farmyard manure is utilized in crop production, there is bound to be better yields as compared to where no manure is used.

The insignificant correlation between number of livestock and number of meals could arise from the fact that livestock as a food source is utilized occasionally. Generally, it is not common practice for households in western Kenya to slaughter livestock for use due to their high monetary value. Also, some households found it unacceptable to consume products such as eggs due to cultural beliefs or ignorance $[4,10]$ hence they sell them. Milk as the most commonly consumed product is incorporated in tea, thus not affecting the number of meals but affects the quality of the meal. Further, the fact that households in Butere division rear few livestock could mean that the effect of livestock on number of meals is negligible.

Generally, studies have revealed that there is potential for home gardening to enhance food and nutrient security, as well as for income generation [3, 17, 19, 20, 21]. Studies done to promote home gardening in Nepal and in Kinshasa revealed that home gardening can be used for year round supply of food to households. In Northern Thailand, home gardens were successfully used in a study to control vitamin A deficiency $[3,20,21]$. These cases show that home gardening can improve livelihoods of rural communities if promoted and supported.

\section{RECOMMENDATION}

From the findings of this study, the following recommendations were made:

- There should be dispensation of existing information on home gardening using a diversity of methods accessible to the rural households. Presently, agricultural extension is the only significant method of information dispensation and the department is overwhelmed. This means that information does not reach many households who would otherwise improve their practice of home gardening for food security.

- Households practicing home gardening should be discouraged from selling their produce until the household's food requirements are met. This could be achieved by encouraging increased production of home garden foods to allow for surpluses, which can be sold for income.

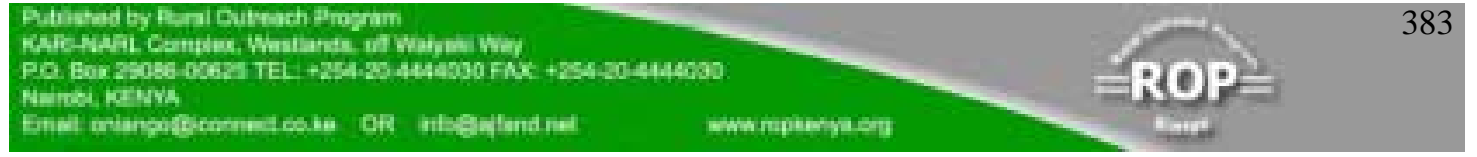


- Stakeholders in agriculture and food security agencies should offer feasible alternatives that emphasize food crop farming in favor of cash crop farming to households. This would enhance food crop production instead of cash crops thus households will be food secure.

- Farmers/households should have access to funds that will offer them capital for investment. Presently, women and youth can access loans through the Constituency Development Fund.

- The government, through the Ministry of Roads and Public works needs to improve infrastructure in the division and the district at large as some parts of the roads become impassable in the rainy seasons. This would assist in the marketing of farm produce.

\section{CONCLUSION}

This study was carried out to determine the role of home gardening in household food security in Butere division, western Kenya. Findings have revealed that food security is an issue of concern in the division as many households are affected by seasonal hunger. Results have shown that home gardening plays a role in household food security with regard to size of land and number of livestock but not with home garden crops. Although agricultural production was identified as the main method of food procurement for households, it is apparent that home gardening is not an established practice in Butere division. The neglect of home garden crops in favor of sugarcane as a cash crop and other field crops could have adverse effects on the food security status of households. There is urgent need to recognize the potential of home gardening, as there is evidence through research, that it can improve household food security. Butere division can take advantage of the high agro-biodiversity to secure more food crops at household level. With the high population density in this division, only intensive practices of crop production provided through home gardening will ensure food security for households and the community at large. Further research is suggested in the following areas:

- Nutritional status assessment of households in Butere division to ascertain the role of home garden foods in nutrient security

- Effects of gender and land ownership on home gardening

- Preservation techniques for home garden foods that could be adopted by the rural households. 


\section{ACKNOWLEDGEMENT}

I acknowledge a number of people, many more than I can mention, who have been very instrumental in seeing this work, being part of research for Master of Science thesis at Maseno University come to completion. I thank my co-authors, Professors Asenath Sigot and Mary Abukutsa Onyango and also Prof. Ruth Oniang'o and the Rural Outreach Program (ROP) for supporting the pilot study and the main study. This work had the partial funding of International Plant Genetic Resource Institute (IPGRI) and the Institute of Research and Post-graduate Studies at Maseno University. 
Table 1: Distribution of households by home garden crops grown

\begin{tabular}{|l|ll|l|}
\hline Crops & $\begin{array}{l}\text { Number } \\
\text { households }\end{array}$ & of & \\
\hline Maize & 99 & 99.0 \\
Legumes & 96 & 96.0 \\
Vegetables & 99 & 99.0 \\
Bananas & 80 & 80.0 \\
Root crops & 69 & 69.0 \\
Nuts & 45 & 45.0 \\
Sorghum & 16 & 16.0 \\
Millet & 15 & 15.0 \\
& & \\
\hline
\end{tabular}


Table 2: $\quad$ Distribution of households by number of livestock reared

\begin{tabular}{|c|c|c|}
\hline Particulars & $\begin{array}{l}\text { Number } \\
\text { households }\end{array}$ & Percent \\
\hline $\begin{array}{l}\text { Cattle }^{1} \\
\text { None } \\
1-3 \\
4-6 \\
7-9 \\
10-12\end{array}$ & $\begin{array}{l}26 \\
52 \\
18 \\
3 \\
1\end{array}$ & $\begin{array}{r}26.0 \\
52.0 \\
18.0 \\
3.0 \\
1.0\end{array}$ \\
\hline $\begin{array}{l}\text { Sheep }^{2} \\
\text { None } \\
1-5 \\
6-10 \\
11-15\end{array}$ & $\begin{array}{r}78 \\
20 \\
1 \\
1\end{array}$ & $\begin{array}{r}78.0 \\
20.0 \\
1.0 \\
1.0\end{array}$ \\
\hline $\begin{array}{l}\text { Goats }^{3} \\
\text { None } \\
1-5 \\
6-10\end{array}$ & $\begin{array}{r}92 \\
7 \\
1\end{array}$ & $\begin{array}{r}92.0 \\
7.0 \\
1.0\end{array}$ \\
\hline $\begin{array}{l}\text { Poultry }^{4} \\
\text { None } \\
1-10 \\
11-20 \\
21-30 \\
31-40 \\
\end{array}$ & $\begin{array}{r}7 \\
73 \\
13 \\
2 \\
5 \\
\end{array}$ & $\begin{array}{r}7.0 \\
73.0 \\
13.0 \\
2.0 \\
5.0\end{array}$ \\
\hline $\begin{array}{l}\text { TOTAL PER } \\
\text { CATEGORY }\end{array}$ & 100 & 100.0 \\
\hline
\end{tabular}




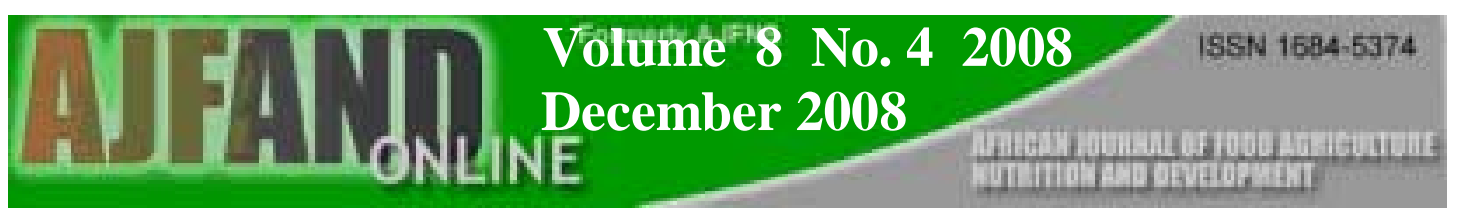

Table 3: $\quad$ Pearson Correlation Coefficient data

\begin{tabular}{|c|c|c|c|c|c|}
\hline Correlation & Size of land & Food stock & $\begin{array}{l}\text { Number of } \\
\text { meals }\end{array}$ & $\begin{array}{l}\text { Home garden } \\
\text { crops }\end{array}$ & $\begin{array}{l}\text { Number of } \\
\text { livestock }\end{array}$ \\
\hline $\begin{array}{l}\text { Size of land } \\
\text { Pearson } \\
\text { correlation } \\
\text { Sig. (2-tailed) } \\
\text { N }\end{array}$ & $\begin{array}{l}1.000 \\
. \\
100\end{array}$ & $\begin{array}{l}.336 * * \\
.001 \\
100 \\
\end{array}$ & $\begin{array}{l}.133 \\
.188 \\
100 \\
\end{array}$ & & \\
\hline $\begin{array}{l}\text { Food stock } \\
\text { Pearson } \\
\text { correlation } \\
\text { Sig. (2-tailed) } \\
\text { N }\end{array}$ & $\begin{array}{l}.336 * * \\
.001 \\
100\end{array}$ & $\begin{array}{l}1.000 \\
100\end{array}$ & & $\begin{array}{l}.117 \\
.248 \\
100 \\
\end{array}$ & $\begin{array}{l}.211 * \\
.035 \\
100 \\
\end{array}$ \\
\hline $\begin{array}{l}\text { No. of meals } \\
\text { Pearson } \\
\text { correlation } \\
\text { Sig. (2-tailed) } \\
\text { N }\end{array}$ & $\begin{array}{l}.133 \\
.188 \\
100 \\
\end{array}$ & & $\begin{array}{l}1.000 \\
100\end{array}$ & $\begin{array}{l}.000 \\
1.000 \\
100\end{array}$ & $\begin{array}{l}.064 \\
.527 \\
100-\end{array}$ \\
\hline $\begin{array}{l}\text { Home garden } \\
\text { crops Pearson } \\
\text { correlation } \\
\text { Sig. (2-tailed) } \\
\text { N }\end{array}$ & & $\begin{array}{l}.117 \\
.248 \\
100\end{array}$ & $\begin{array}{l}.000 \\
1.000 \\
100\end{array}$ & $\begin{array}{l}1.000 \\
100\end{array}$ & \\
\hline $\begin{array}{l}\text { Number of } \\
\text { livestock } \\
\text { Pearson } \\
\text { correlation } \\
\text { Sig. (2-tailed) } \\
\text { N }\end{array}$ & & $\begin{array}{l}.211^{*} \\
.035 \\
100\end{array}$ & $\begin{array}{l}.064 \\
.5227 \\
100\end{array}$ & & $\begin{array}{c}1.000 \\
100\end{array}$ \\
\hline
\end{tabular}




\section{REFERENCES}

1. Sigot AJ Indigenous Food Systems: Creating and Promoting Sustainable Livelihoods. Proceedings of the International Conference on Indigenous Knowledge Systems: African Perspectives. Thohoyandou, South Africa, 2001: $1-6$.

2. FAO. Improving Nutrition through Home Gardening. A training package for preparing field workers in Africa. Rome, 2001: 11-22.

3. Shrestha P, Gautam R, Rana BR and B Sthapit Home Gardens in Nepal, status and scope for research and development. In WJ. Watson \& PB. Eyzaguirre (Eds). Home Gardens and in situ conservation of plant genetic resources in farming systems. Proceedings of the second international Home Gardens workshop. Rome, IPGRI 2001: 105-117.

4. Republic Of Kenya Butere-Mumias District Poverty Reduction Strategy Paper 2001-2004. Government Printer, 2001: 5-7, 10-13, 48-49.

5. Oniang'o RK Enhancing People's nutritional status through revitalization of Agriculture and Related activities. In African Journal of Food and Nutritional Sciences. Vol. 1 No.1 August, 2001: 43-49.

6. Republic of Kenya Second report on Poverty in Kenya Volume 1: Incidence and Depth of Poverty. Government Printer, 2000: 7-9, 26-27.

7. ACC/SCN Symposium Report Nutrition and Poverty. Nutrition Policy Paper No.16. Papers from the $24^{\text {th }}$ Session Symposium Kathmandu. United Nations, 1997: 69-76.

8. Latham $\mathbf{M}$ and $\mathbf{M}$ Beaudry The impact of transnational corporations on food consumption and nutrition in Africa. In A. Ogunrinade with R. Oniang'o and J. May (Eds). Not by Bread Alone; Food Security and Governance in Africa. South Africa: Toda Institute for Global Peace and Policy Research, 1999: 222241.

9. Mason JB, Habicht JP, Tabartabai $H$ and V Valverde Nutritional Surveillance. Geneva, 1984: 19-20.

10. Republic of Kenya Butere-Mumias District Development Plan (2002-2008). Government Printer, 2001: 7-9, 26-27.

11. Mason JE and JW Bramble Research in Education and the Behavioral Sciences, Concepts and Methods. Mexico City, Brown and Benchmark Publishers, 1997. 
12. Mugenda MO and GA Mugenda Research Methods. Quantitative and Qualitative Approaches. Nairobi, ACTS Press, 1999: 155-179.

13. Lapin L Statistics: Meaning and Method, $2^{\text {nd }}$ Ed. New York, 1980: 13-17; 308315.

14. Robson C Real World Research. Blackwell Publishers, Oxford: 1993.

15. Maxwell S and TR Frankenberger Household food security: Concepts, indicators, measurements. A technical review. New York, UNICEF; Rome, IFAD, 1992: 79-108.

16. Republic of Kenya Sessional Paper No.2 of 1994 on National Food Policy. Government Printer: 1994.

17. FAO. Agriculture, food and nutrition for Africa. A resource book for teachers of agriculture. Rome FAO 1997: 139-148.

18. Maundu WP, Ngugi WG and HSC Kabuye Traditional Food Plants of Kenya. Nairobi, Kenya Resource Centre for Indigenous Knowledge (KENRIK), 1999: $1-3$.

19. Muelhoff $\mathbf{H}$ How home gardens can significantly contribute to good nutrition year round. Rome, FAO: 2001.

20. Midmore DJ, Ninez $\mathbf{V}$ and $\mathbf{R}$ Venkataraman Household gardening project in Asia, past experience and future direction. In Food, Nutrition and Agriculture: Strategies to combat micronutrient deficiencies. Rome 1991.

21. Mpoyi K and SJ Paulus Promoting home gardening in Kinshasa, Zaire. In Traditional African Vegetables. Proceedings of the IPGRI International Workshop on Genetic Resources of Traditional vegetables in Africa: Conservation and use. Rome, FAO 1997. 